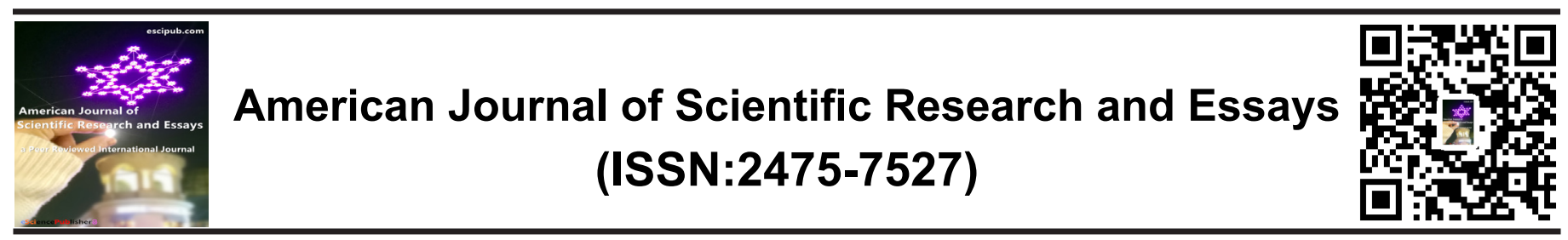

\title{
Market Chain Analysis of Koka Reservoir Fish in Ethiopia
}

\author{
Abebe Cheffo ${ }^{1}$, Lemma Zemedu (PhD) ${ }^{2}$ and Endrias Geta (PhD) ${ }^{2}$
}

${ }^{1}$ National Fishery and Other Aquatic Life Research Center P.O.Box 64 Sebeta

${ }^{2}$ Haramaya University, Department of Agricultural Economics P.O.Box 138 Dire Dawa

\section{ABSTRACT}

This study analyzed the fish market chain of Koka reservoir in Ethiopia which is found in Oromia Region, East shoa and Arsi zones. The objectives of the study were to assess the structure, conduct and performance of fish marketing as well as identify factors affecting fish market supply. The study was based on the data obtained from a sample of 104 fishers and 36 traders in the fish market chain. Both descriptive and econometric methods were employed to analyze the data. About $65 \%$ Tilapia (Coroso), $21 \%$ Catfish (Ambanza) and 14\% Carp (Abasamuel) were the type of fish which dominantly appear in the day to day marketing activities of the fishers. The major determinant factors of market supply were estimated by using multiple linear regression models. The fish market performance was also measured using indicators of marketing margins. According to the results, there were three kinds of fish marketing channels i.e fishers to consumers, fishers to retailers then consumers, fishers to fishery cooperatives, wholesalers then consumers. The result showed that transportation and filleting costs were the largest costs of marketing followed by gutting cost. The price of a kilogram of filleted tilapia varied from 18 birr at landing site to 75 birr at Atiklt Tera in Addis Ababa. The Ordinary Least Square results indicated that education level, availability of credit facility and ownership of fishing license significantly affected the amount of fish supplied to market by fishers in the study area. Expanding adult education in fishery community, facilitating access to credit facility and encouraging fishers to be legal is very important for better harvesting and marketing of fish.

Key words: Tilapia, catfish, carp, marketing channels, marketing cost
*Correspondence to Author:

Abebe Cheffo, national Fishery and Other Aquatic Life Research Center P.O.Box 64 Sebeta,

Email: felkacheffo@gmail.Com

How to cite this article:

Cheffo et al. Market Chain Analysis of Koka Reservoir Fish in Ethiopia. American Journal of Scientific Research and Essays, 2016,1(1): 0042-0053.

\section{eSciencePublisher}

eSciPub LLC, Houston, TX USA. Website: http://escipub.com/ 


\section{INTRODUCTION \\ 1.1 Background of the Study}

Globally, fish is a valuable traded commodity, representing a significant source of foreign exchange earnings, in addition to its important contributions to employment creation, income generation and food security. In 2008, about 39 percent (live weight equivalent) of world fish and fishery products was internationally traded as various food and feed products, compared with 25 percent in 1976 (FAO, 2010a). This increase in volume is a reflection of the sector's growing degree of openness to and integration in, international trade. Some of the specific factors that have contributed to this rise are: growing globalization of the fishery and aquaculture value chain; outsourcing of processing to countries where comparatively low wages and production costs provide a competitive advantage; increasing consumption of fishery commodities; favorable trade liberalization policies; and technological innovations, including improvement in processing, packaging, transportation and changes in distribution and marketing that have significantly changed the way fishery products are prepared, marketed and delivered to consumers (FAO, 2010a).

Fish and the fisheries sector are of great social and economic importance to Malawi. The sector plays a very significant role as a source of nutrition, income and employment. Fish provides over $60 \%$ of the dietary animal protein intake of Malawians and $40 \%$ of the total protein supply. Much of the fish is consumed in rural areas thereby contributing significantly to daily nutritional requirements of poor rural masses. Fish acts as a source of income for the people of Malawi, generating beach price local revenue of about MK2.6 billion (US\$24million) annually. (Letson et al., 2012).

Ethiopia covers a total area of 1.1 million $\mathrm{km}^{2}$ and an estimated population of 82 million in 2010 (Belay, 2010). The total water bodies have surface area estimated at $7334 \mathrm{~km}^{2}$ of small water bodies and $7185 \mathrm{~km}$ long rivers. Nearly half of the area is covered by major lakes and reservoir around $3500 \mathrm{~km}^{2}$ is covered by Lake Tana, which is the largest lake in the country and source of Abby river in the Nile basin. All major lakes, except Lakes Tana, Ardibo and Lugo are found in the rift valley (FAO, 2003). The country has huge potential of fish production by which the production of fish from major lakes reaches up to 23,342 ton per year, from major reservoir and dams 4,399 ton per year, from small water bodies 1,952 ton per year and from rivers 21,788 ton per year (Bernard et al, 2003).

\subsection{Trends in Fish Production and Consumption in Ethiopia}

After the departure of Eritrea from Ethiopia in 1993 and the resulting loss of its coastline, Ethiopia has only inland freshwater capture fisheries. In Ethiopia, the current annual per capita fish consumption is less than 240 gram per year .At Addis Ababa, the figure is about $1 \mathrm{Kg}$ per year, while in towns located in fish production areas (Bahirdar, Ziway, Arbaminch, Hawassa and Gambella per capita fish consumption is estimated at $10 \mathrm{Kg}$ per year ( Solomon, 2009).Despite this based on only a single factor - population-current annual demand for fish in the country is estimated at 65,344 ton, equivalent to $0.797 \mathrm{~kg} /$ person. Future demand at the present population growth rate will reach 94,526 ton in 2015 and 117,586 ton in 2025. This is the minimum demand, since factors other than population are not considered here. These positive factors which activate demand include the relatively low price of fish or the increasing prices of its substitutes; a rise in income; and improvement and expansion in fish distribution or supply networks and improvement in fish product quality. These factors may increase the projected demands by as much as 15 to 20 percent. Those factors that retard effective demand for fish require to be addressed through education, fish consumption promotion and product development (FAO, 2008).

\subsection{Objectives of the Study}

The general objective of the study was to assess market chain of fish from Koka reservoir.

The specific objectives were:

$>$ To identify the major fish marketing channels,

> To identify the role and conduct of marketing agents

To quantify costs for key marketing actors 
$>$ To quantify margins for key marketing actors

$>$ To identify factors affecting fish supplied to the market by fishers in the study area

\subsection{Factors Affecting Market Supply of Fish}

Post harvesting and marketing activities are critical factors for the supply of fish included daily and seasonal price fluctuations due to changes in supply volume; poor health and hygiene in wholesale and retail markets; limited experience and knowledge about export markets; lack of value-addition and processing; and steady increases in fish supply coupled with poor consumer perceptions of farmed fish quality leading to declining consumer prices (Ahmed etal.2012).

The flow of market information is essential to promote a fair and transparent market mechanism. An increase in supply of raw fish may depress prices on the local markets due to the limited purchasing power of consumers (Soobasch ,2009). According to Rab et al (2006), fish harvested by fishers was immediately landed (i.e. at the landing site or harbor), and transferred to fish collectors and/or fish processors. Sometimes, harvested inland fishes were kept alive in pens or cages for sale during periods, when supply was scarce and prices were more satisfactory. Before reaching the consumer, fish and fish products would have passed through a number of transactions including fisher, fish collector, landing site owner, fish processor, distributor, retailer etc.

In fish harvesting and marketing, there are a variety of forms of rent. It may range from high cost of operation, high fixed cost, control, and access to premium services, access to information and marketing intelligence, etc. These barriers to entry will inhibit the new player to enter the trade easily. The barrier to mobility makes it difficult for the existing player to move the trade operation from one location and other. Exit barriers are the barriers that make it difficult for the existing players to quit the business operation. In case of fishery market, the exit barrier lies in form of huge capital investment etc.which makes it difficult for the operator to quit business (Raja, 2005).

\section{RESEARCH METHODOLOGY}

\subsection{Description of the Study Area}

Koka reservoir is found in Oromiya Regional State, East Shoa Zone (Lome and Bora Weredas), and Arsi Zone (Dodota Wereda). The reservoir has $255 \mathrm{~km}^{2}$ area, maximum depth of 14 meters, minimum depth of 9 meters, maximum length of 20 kilometers, maximum width of 15 kilometers, shore line of 195-205 kilometers and water temperature of $20^{\circ} \mathrm{C}$. It is located at $8^{\circ} 26^{\prime} \mathrm{N}$ latitude, 39 $10^{\circ} \mathrm{E}$ longitude and an altitude elevation of 1660 meters above sea level. There are many species of fish in the reservoir while Orechromis niloticus (Tilapia), Cyprinus Carpio (Common Carp), Clarias gariepinus (Catfish),and Barbus intermedius (Barbus) are commercially important species. The reservoir was constructed in late 1950s for hydroelectric power generation purpose on Awash River. It is situated at around 90 kilometers southeast of Addis Ababa (Gashaw.2006).

\subsection{Types and Sources of Data}

The sources of data for this study were both primary and secondary data sources. Secondary data were collected from different published and unpublished sources, such as government institutions, research reports, bulletins, and websites.

The primary data that were collected from fishers by using questionnaire include factors affecting fish market supply, size of catch, market information, credit access, and access to market, number of gillnet owned, fish harvesting cost, annual return from fish, agricultural extension service, time of sale, license possession and demographic characteristics of the household. In addition to these, the questionnaire for traders included type of business (wholesaler and retailer), buying and selling strategies, initial capital, current working capital, source of working capital, source of market information, demographic characteristics of the traders and other related data was collected. The study used both quantitative and qualitative data.

\subsection{Sampling Procedure and Sample Size Determination}

To select fishers a multi-stage sampling technique 
Cheffo et al., AJSRE, 2016; Vol. 1(1): 0042-0053

Table 1. Percentage of fishers' market outlet in Dodota, Bora and Lome weredas

\begin{tabular}{ccc}
\hline Market actors & Wereda & \% of fishers' outlet \\
\hline Whole sellers & Dodota & 50 \\
Retailers & & 15 \\
Consumer & Bora & \% of fishers' outlet \\
\hline Market actors & & 30 \\
Whole sellers & 15 \\
Retailers & & 55 \\
Consumer & & $\%$ of fishers' outlet \\
\hline Market actors & Lome & 15 \\
\hline Whole sellers & & 60 \\
\hline Retailers & & 25 \\
Consumers & & \\
\hline
\end{tabular}

Source: Survey result, 2013

Table 2. Traders' concentration ratio in Dodota, Lome and Bora weredas

\begin{tabular}{|c|c|c|c|c|c|c|c|}
\hline $\begin{array}{c}\text { Number of } \\
\text { traders(A) }\end{array}$ & $\begin{array}{c}\text { Cumulative } \\
\text { frequency } \\
\text { of traders } \\
\text { (B) }\end{array}$ & $\begin{array}{c}\text { \% of traders } \\
\text { (C=A36) }\end{array}$ & $\begin{array}{c}\text { Quantity } \\
\text { purchased } \\
\text { in Kilogram /day (E) }\end{array}$ & $\begin{array}{c}\text { Total } \\
\text { quantity } \\
\text { purchased } \\
\text { in } \\
\text { kilogram } \\
\text { (F=AXE) }\end{array}$ & $\begin{array}{c}\text { Total quantity } \\
\text { purchased } \\
\text { in kilogram (F=AXE) }\end{array}$ & $\begin{array}{c}\text { \% share of purchase } \\
\text { (G) } \\
\text { Si=F/8375 }\end{array}$ & $\begin{array}{c}\text { \% cumulative } \\
\text { purchase } \\
\text { (C=) }\end{array}$ \\
\hline 1 & 1 & 2.78 & 2.78 & 1500 & 1500 & 17.91 & 17.91 \\
\hline 1 & 3 & 5.56 & 8.34 & 1200 & 2400 & 28.66 & 46.57 \\
\hline & $36 *$ & 2.78 & 11.11 & 1000 & 1000 & 11.94 & 58.51 \\
\hline
\end{tabular}

*indicates sum of frequency of fish traders

** indicates total quantity of fish purchased by 36 traders

Source; Own computation,2013 
was used. In the first stage a stratified sampling method has been used and Landing sites were categorized as Bora, Lome and Dodota weredas. In the second stage among landing sites from each weredas one landing site was selected randomly. In the third stage, from each landing site fishers were categorized as cooperative members and non cooperative members and selected using proportionate random sampling technique and interviewed. For focus group discussion 6-10 fishers were selected within landing sites and Kebeles leaders in each PAs to supplement the individual interview.

Due to logistics scarcity, the total numbers of respondents of fishers and traders from all sites were 140.

\subsection{Methods of Data Analysis}

In this study descriptive and econometric methods of data analysis were employed. Descriptive statistics like mean, standard deviation and percentile were used to describe basic characteristics of market channel participants. A classical linear regression model was used to analyze fish supplied to market.

\subsubsection{Market concentration measure}

The number, distribution and relative size of sellers and buyers in the market can be measured commonly by concentration ratio. The greater the degree of concentration, the greater will be the possibility of non-competitive behavior, such as collusion existing in the market. The concentration of firms in the market is estimated using the common measure of market concentration ratio.

For an efficient market, there should be sufficient number of firms (buyers and sellers). The method used to study the structure of the market was as follows:

$$
S i=\frac{V i}{\Sigma V i}
$$

where $\mathrm{Si}=$ the percentage market share of the $i^{\text {th }}$ firm

buyer i

$$
\mathrm{Vi}=\text { amount of product handled by }
$$

$\Sigma \mathrm{Vi}=$ Total amount of the product

Market concentration ratio is given by as follows:

$$
\left[C=\sum_{i=1}^{r} s_{i}\right]
$$

Where $\quad \mathrm{Si}=$ the percentage market share of the $i^{\text {th }}$ firm

$r=$ the number of relatively large firm

for which the ratio is going to be calculated

$\mathrm{C}=$ Concentration ratio

\subsubsection{Marketing margins}

A marketing margin is the percentage of the final weighted averages selling price taken by each stage of the marketing chain. The total marketing margin is the difference between what the final consumer who exist at end of different channel pays and what the fisher receives the product. In other words it is the difference between retail price and farm price (Cramer and Jensen, 1982). Computing the total gross marketing margin (TGMM) is always related to the final price paid by the end buyer and it is expressed as percentage (Mendoza and Rosegant,1995).

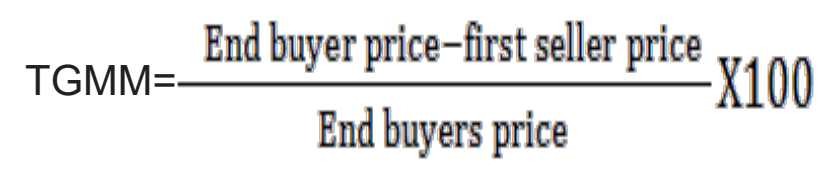

where, $\mathrm{TGMM}=$ Total gross marketing margin

\subsubsection{Econometric analysis}

Following Guajarati (2004), the OLS estimators are expressed solely in terms of the observable (i.e., sample) quantities (i.e., $X$ and $Y$ ). Therefore, they can be easily computed. They are point estimators; that is, given the sample, each estimator will provide only a single (point) value of the relevant population parameter.

The OLS regression is specified as:

$Y=f$ (price, family size, formal education, fishing experience, market information, distance to market, accesses to extension, time of selling, etc.....). Thus,

$$
Y_{i}=a_{+} \beta X_{i}+U_{i}
$$

where $\mathbf{Y}_{\mathrm{i}}=$ marketed supply of fish $\mathbf{U}_{\mathrm{i}}=$ unobserved disturbance term $\mathbf{X}_{i}=$ independent variable , and ' $i$ ' is $1,2,3 \ldots n$ 
$\beta=$ coefficients of $i^{\text {th }}$ independent variable

$\mathbf{a}=$ an intercept

The parameter estimates of the above model may not be Best Linear Unbiased Estimator (BLUE) when some of the assumptions of the Classical Linear Regression (CLR) models are violated, thus, it is important to check the presence multicollinearity among the variables that affect supply of red pepper in the area.

The main independent variables for supply function include:

$\mathrm{X} 1$ = family size of fisher (FAMSIZ)

$\mathrm{X} 2$ education level of the household (EDULEV)

$\mathrm{X} 3=$ distance to market (DISMKT)

$\mathrm{X} 4=$ extension service (DOEXTS)

$\mathrm{X} 5=$ Post harvest training (HAPHTR)

$\mathrm{X} 6=$ Amount of credit received (DYCRFI)

$\mathrm{X} 7=$ Market information (DYGMI)

$\mathrm{X} 8=$ Membership in fishery cooperatives

(DOHMFC)

X9= License ownership (DOHLIC)

$\mathrm{X} 10=$ Experience of fishing (FISEXP)

\section{RESULTS AND DISCUSSION}

\subsection{Demographic and Socioeconomic} Characteristics of Respondents

\subsubsection{Demographic characteristics of sample fishers}

In this part of the thesis, sampled fishers' demographic characteristics (age, family size and education) are discussed. Demographic characteristics are believed to have influence on harvesting and marketing of fishers in different aspects. The mean age of fishers was 38 with minimum and maximum value of 18 and 65 years respectively. The educational background of the sample fishers is believed to be an important feature that determines the readiness of household heads to accept new ideas and innovations. The survey result indicated that $36.54 \%$ of respondents were illiterate and the rest percentage shared by educational level of writing and reading skill up to grade 12 . The mean family size was 5 and all fishers were male.

\subsubsection{Demographic characteristics of traders}

The survey result indicates that the men age of respondents was 32 with minimum and maximum value of 22 and 50 respectively. The mean value of family size was 3 with the range of 1 to 7 minimum and maximum family sizes respectively. The education level ranges zero (illiterate of $5.6 \%)$ to grade $12(11.11 \%$ ) and mean grade of 6 .

\subsubsection{Socioeconomic characteristics of traders}

The socioeconomic characteristics of traders include the physical and financial assets such as refrigerators, balance, telephone (fixed or mobile), vehicles, motor cycle, animal driven cart and source of working capital. The survey result indicates that all the sample traders store the fish by using refrigerators on the average for 5 days before sale. From the total respondents $95 \%$ of them have a separate refrigerator for storing fish while $5 \%$ use shared refrigerators with home usage.

\subsection{Structure, Conduct and Performance of Fish Market}

The salient features of market structure are: the degree of sellers and buyers' concentration, the degree of product differentiation among the outputs of the various sellers in the market, and barriers to entry or freedom to entry and exit from the market. Market structure is analyzed based on the numbers and sizes of enterprises within the system, and the potential access of additional participants to it (licensing procedure, lack of capital and know how, and policy barriers) and the degree of transparency (Pender etal., 2004). In this study, the structure of the fish market is characterized by fish market participants, marketing channels, market concentration, and degree of transparency.

\subsubsection{Fish market actors and their role in the channels}

Freshwater fishers operate at household level. They often use family labor and hired labor is necessary for their business. Nearly half (48 percent) of the fishers often acted as retailers, selling fish directly to final consumers in local markets (Audun, etal,2004). Out of the total sampled respondents who were asked about the type of fish they dominantly caught, they respond 65\% Tilapia (Coroso), 21\% Catfish (Ambanza) and $14 \%$ Carp(Abasamuel).Fishers who do 
not have membership in fishery cooperatives in Metoaleka and Kenteri as well as fishers of Amude landing site have no refrigerator for preserving fish. Thus they were forced to sell their caught right after they remove the fish from the reservoir.

Fishers' Cooperatives: In the case of freshwater capture fisheries, there is another intermediary, who may be either a private contractor or fishermen co-operative. In this system, fishers dispose catch through cooperative/contractor. If the fishing rights of a water body are with a private/public body, i.e. contractor/ co-operative, fishers are paid for fishing and their compensation depends on the bargaining power of the fisher/ contractor (B.Ganesh etal, 2008).

Wholesaler:Wholesale traders can besubdivided into rural assembling traders, collecting wholesalers and distributing wholesalers (Lutz, 1994 and Dijkstra 1997). They usually know the demand of species outside markets and are aware of average trend of daily fish catches at the landing centers (Bishnoi, 2005).

Retailer: Retailers form a nationwide retailing network in Vietnam and generate income for the market operators, supply different forms of fish products, and contribute to market stabilization (Audun L, etal, 2010)

\subsubsection{Fish marketing channels}

Three main alternative channels were identified for fish marketing in the study area. The main marketing channels identified from the point of harvesting until the product reaches the final consumer through different intermediaries were:

Chanel I Fishers - Consumers (Landing sites) Chanel II Fishers - Retailers - Consumers (Landing site \& towns nearby landing sites) Chanel III Fishers - Fishery cooperatives Whole seller - Consumers (Adama, Atiklt-Tera (Addis Ababa))

As can be seen from the marketing channels, there are actors between the fishers and consumers. The actors involved in these channels were fishers, retailers and wholesalers (Table 1).
As Table 1 indicated, there were differences in percentage of fishers' share between market outlets among landing sites. The market outlet is share of sell at which each actor can take from the total sell of fish. At Dodota wereda, the share of wholesaler was 80 percent and followed by Consumers. Whole sellers took the highest share of outlet and this share indicated that the market is dominated by a few individuals which have oligopoly nature. At Bora wereda, consumers dominate by 55 percent and followed by whole sellers. Similarly at Lome wereda, consumers dominate by 60 percent and followed by wholesalers. These market outlets tell us the fishers are price takers in Amude landing site at which wholesalers set the price and fishers are forced to sell his catch in whatever price set by wholesalers. Fishers do have two choices for their catch i.e. either sell with the price delivers by his buyer or distribute it to his relatives nearby or dump it to the reservoir. So in whatever cases he prefers the former and search other catches.

\subsubsection{Measure of market concentration ratio}

A market concentration ratio is a measure of the percentage share of the market controlled by a specified percentage of farms ranked in order of market share from largest to the smallest (Karugain,1990). Table 2 indicates that the four large firms handled $58.51 \%$ of the total volume of fish purchased per day. This percentage indicates that there is strong oligopolistic nature of traders. Similarly, study conducted by Pomerory (1989) on four fish market using concentration ratio (market share ratio) in Philippines found that $50 \%$ of the fish traders in the industry made $80 \%$ of the fish purchases.

\subsection{Performance of Fish Market}

The performance of fish market was evaluated by considering associated costs, returns and marketing margins. Table 3 shows marketing costs and profit margins of fish in the three channels for each group of market player. Channel I represents direct selling from fishers to consumers. Channel II represents selling of fish from fishers to consumer through retailers. The last channel, channel III represents selling of fish from fishers to consumers through wholesalers. From Table 3 it can be seen that, the largest 
Cheffo et al., AJSRE, 2016; Vol. 1(1): 0042-0053

Table 3. Marketing costs, selling price and profit of traders (Birr/fish/kilogram)

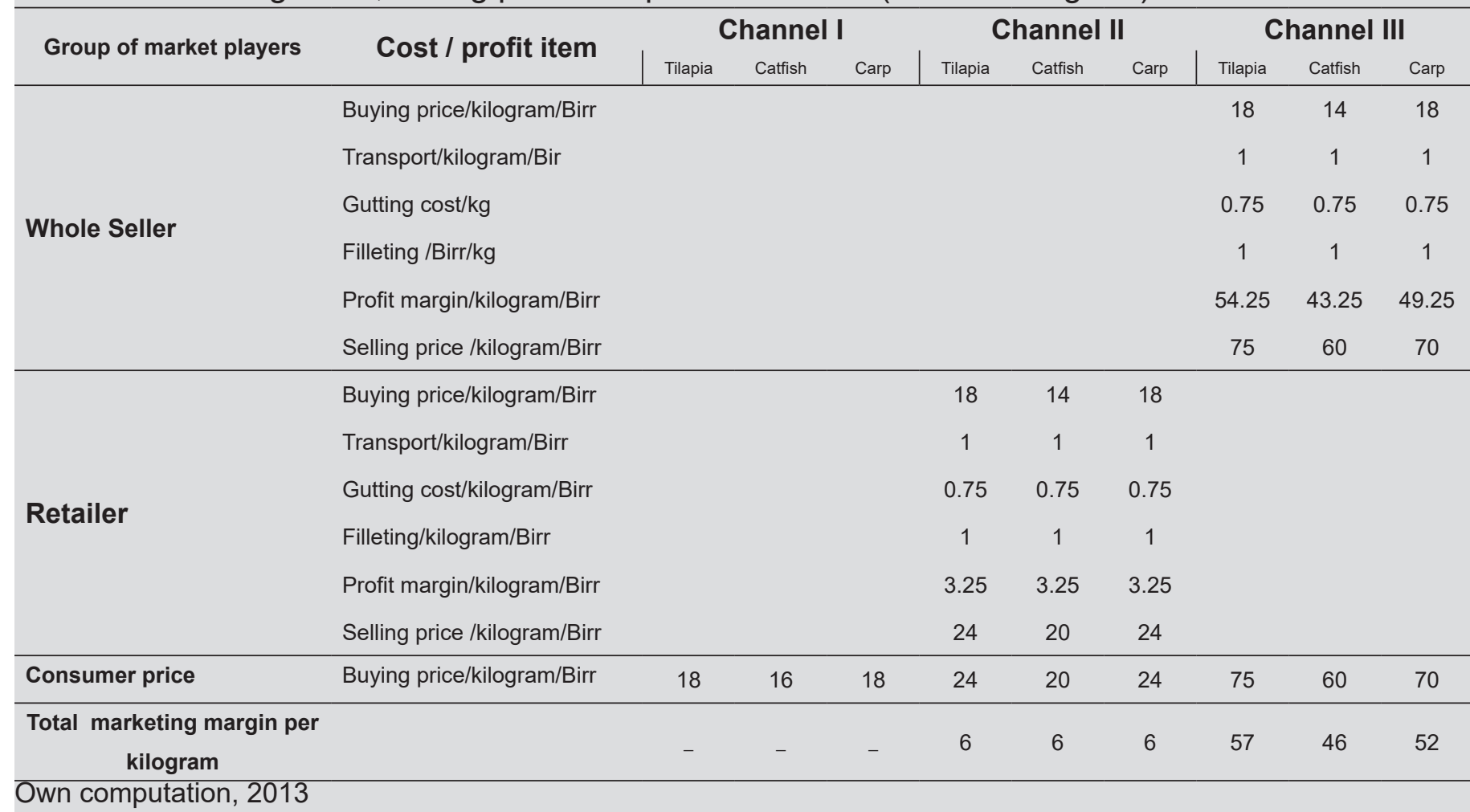

Table 4 . Percentage marketing margins for different marketing channels

\begin{tabular}{|c|c|c|c|c|c|c|c|c|c|}
\hline \multirow{3}{*}{$\begin{array}{c}\text { Marketing } \\
\text { margins }\end{array}$} & \multicolumn{9}{|c|}{ Market Channels } \\
\hline & \multicolumn{3}{|c|}{1} & \multicolumn{3}{|c|}{ II } & \multicolumn{3}{|c|}{ III } \\
\hline & Tilapia & Catfish & Carp & Tilapia & Catfish & Carp & Tilapia & Catfish & Carp \\
\hline TGMM\% & & & & 25 & 30 & 25 & 76 & 76.7 & 74.3 \\
\hline $\mathrm{GMM}_{\mathrm{F}}$ & 100 & 100 & 100 & 75 & 70 & 75 & 76 & 76.7 & 74.3 \\
\hline $\mathrm{GMM}_{\mathrm{R}}$ & & & & 75 & 70 & 75 & & & \\
\hline $\mathrm{GMM}_{\text {ws }}$ & & & & & & & 72.33 & 43.25 & 70.36 \\
\hline $\mathrm{NMM}_{\mathrm{F}}$ & 100 & 100 & 100 & 13.54 & 13.54 & 13.54 & & & \\
\hline $\mathrm{NMM}_{\mathrm{R}}$ & & & & 13.54 & 16.25 & 13.54 & & & \\
\hline $\mathrm{NMM}_{\mathrm{ws}}$ & & & & & & & 72.33 & 72.1 & 70.36 \\
\hline
\end{tabular}

Source: own computation, 2013. Where TGMM-Total Gross Marketing Margin , GMMF - Gross Marketing Margin of fishers, GMMR - Gross Marketing Margin of retailers, GMMWS- Gross Marketing Margin of wholesaler, NMMF- Net marketing margin of fishers, NMMR- Net marketing margin of retailers and NMMWS- Net marketing margin of whole sellers.

Table 5. Sampled fishers access to services

\begin{tabular}{lcccc}
\hline \multirow{2}{*}{$\begin{array}{l}\text { Variables } \\
\text { Responses }\end{array}$} & \multicolumn{3}{c}{ Locations (Landing site) } \\
\cline { 3 - 5 } & & Amude (\%) & Metoaleka (\%) & Kenteri (\%) \\
\hline \multirow{2}{*}{ Access to credit } & Yes & 15.4 & 15.4 & 7.7 \\
& No & 84.6 & 84.6 & 92.3 \\
\hline \multirow{2}{*}{ Access to extension } & Yes & 7.7 & 7.7 & 0 \\
& No & 92.3 & 92.3 & 100 \\
\hline Access to market infor- & Yes & 15.4 & 30.8 & 30.8 \\
mation & No & 84.6 & 69.2 & 69.2 \\
\hline
\end{tabular}

Source; Own computation, 2013 
contribution of market costs was for transportation and filleting in channel II and III. In addition to this gutting cost was the highest marketing cost. Marketing margins of fish traders as a proportion to final consumer price were calculated. Profit margin for wholesaler in channel III was 54.25 , 43.25 and 49.25 birr per kilogram from Tilapia, Catfish and Carp respectively. Profit margin for retailer in channel II was 3.25 birr each per kilogram from Tilapia, Catfish and Carp respectively.

\section{Marketing margin}

As mentioned earlier marketing margin is the difference between the price paid by consumers and that obtained by fishers. Based on the reported prices by the different market participants, summarized in Table 4, the gross and net margins for different marketing channels are calculated as follows.

\subsection{Access to Services}

Access to different services could be essential to improve catching of fishers'. More specifically, access to credit, extension contact and market information are the most important factors that promote fishery sector thereby increasing marketable surplus and ultimately income from fishery.

\subsubsection{Access to credit}

According to the survey results (Table 4), only $15.4,15.4$ and 7.7 percent of sampled fishers in Amude, Metoaleka and Kenteri landing sites respectively had access to credit. Unavailability or low level of credit facilities make fishers not to buy different type of mesh as well as motorized boat which uses for supply of more fish to market.

\subsubsection{Access to extension}

Overall agricultural extension service was very poor in all sampled landing sites. The study result showed that only $7.7 \%$ of respondents at Amude and Metoaleka landing sites had access to extension services. While none of fishers at kenteri landing site had this access. Thus, majority of fishers did not get updated information regarding prices of fish at different level of market. Extension workers found in three wereda have no skill on fishery and they cannot tell anything more than fishers know.

\subsubsection{Access to market information}

The responses of majority fishers (Table 4) indicated that $15.4,30.8$ and 30.8 percent of respondents at Amude, Metoaleka and Kenteri landing sites respectively had market information respectively. The remaining respondents had real problem of getting market information.

\subsection{Constraints and Opportunities of Fish Harvesting and Marketing}

There are a number of constraints as well as opportunities of fish harvesting and marketing. These constraints hinder the large harvest of fish from Koka reservoir and thus reduced income for fishers from fishing.

\subsubsection{Harvesting and marketing constraints}

There were a number of harvesting constraints in the study areas. Some of them were existence of illegal fishers who use very small mesh size which cause depletion of fish genetic resources, chemical discharge from tanneries as well as flower farms nearby reservoir and high robbery risk on mesh as well as hooks are the major harvesting problems. Fishers were asked about some of corrective measures they took to reduce these problems. They have listed; controlling illegal fishers not to use undersized mesh, developing a program for keeping their mesh from theft and trying to convince wereda experts of office of agriculture in order to voice together with them for reducing the discharge rate of chemical wastes from tanneries and flower farms.

There were also fish marketing constraints. In most marketing situations, local retailers as well as whole sellers from Adama and Addis Ababa are simply set price of fish at landing sites without considering current price of fish in Adama and Addis Ababa. High cost of transportation to nearby towns especially from Amude landing site to Dera towns, lack of value adding facilities, relatively less culture of fish eating in the towns near by landing sites were major cause of low price of fish. Fishers were 
responding for the corrective measures for these marketing problems. As table 14 indicated, majority of respondents prefer selling their catch immediately and a few of them try to elongate its shelf life by using different cultural mechanisms.

\subsubsection{Production and marketing opportunities of fish}

Fishers create unity at Amude landing site for developing restrictive rules for preventing the catch of small sized fish which preserves fish genetic resources. In addition to this, some of illegal fishers at Metoaleka and Kenteri landing sites are now becoming members in fishery cooperative and this helps to reduce robbery risk. Landless young farmers and disadvantaged group can involve in fishing activities. The newly constructed road from Dera town to Amude landing site is a good opportunity for fishers to get more markets for their catch. The road is concrete and serves year round. This happens because fish meat could be a substitute for ruminant meat.

\subsection{Econometric Results of OLS Model}

Ten explanatory variables were hypothesized to determine for fishers household level marketable supply of fish. Among these only three variables i.e., education level, credit facility and ownership of fishing license were found to be significantly affecting the household's marketable supply of fish (Table 5).

Amount of credit received (DYCRFI): The result of OLS model showed that this variable has a significant Positive influence on fish supply in the study area. This result is completely in agreement with the prior expectation. This might be due to the fact that households who have got the opportunity to receive more credit would build their capacity to catch more fish through purchase and use of mesh and boat. It would also be possible for the households to spend the credit on some other income generating activities so that the income from these activities puts households in a better status for buying new mesh or maintaining the existing mesh. In addition to these fishers can escape the hardest time of low harvesting of fish by doing off fishing activities. According to Edilegnaw, 2000, credit is expected to increase farm efficiency, the flexibility of farmers' decisions, and then helps to attain economies of scale in production, and consumption smoothing. This result also supported by the research undertaken by M.A. Amin etal, 2012 in Bangladesh. Their result indicated that, fishers who took credit can supply more dry fish than who do not have this access.

Education (EDULEV): Education is positively and significantly related to the supply of fish in the study area. The possible reasons are literate fishers are more willing to adopt better harvesting technologies of using appropriate mesh size, accept technical advice from extension workers especially post harvest handling and saving their money for buying modern fishing equipments. As a result literacy reduces the risk of depletion of fish genetic resources by abstaining from using small sized mesh. According to Dawit, 2010, while education was negatively and statistically significant at less than 10 percent significance level for poultry market participation. This result could be because of the fact that educated household heads have know how on family nutrition requirement rather than participating in the market.

License ownership (DOHLIC): License ownership is positively and significantly related to the supply of fish in the study area. It has expected positive effect on the supply of fish to the market. The possible reasons are fishers are more freedom to catch fish, they do have a full right to catch any time without any restriction over unlicensed fishers in addition to this, there is no any risk of losing their mesh as well as hook. Fishers who has membership in fishery cooperatives have license and keep their mesh from external theft by arranging regular inspection program among members. According to Bram, 2013, for controlling the number of fishers, boat and gear, a system of fish licensing was reintroduced, whereby fishermen have to pay license fees according to the gear they use and they do have legal right to fish in any part of water body and in any time. Formally, this is the main system restricting whereby newcomers have to bring reference letter their former village headman underwriting their character.

\section{SUMMARY, CONCLUSION AND}




\section{RECOMMENDATIONS}

\subsection{Summary}

This study was aimed at analyzing market chain analysis of Koka reservoir fish in Ethiopia. The objectives of the study were identifying the major fish marketing channels, the role and conduct of marketing agents, and quantifying costs and margins for key marketing channels as well as identifying factors affecting fish supply. The data were collected from individual interview from a sample of 140 respondents using pre-tested questionnaire. Primary data were supplemented by secondary data collected from different published and unpublished sources. The analyses were made using descriptive statistics and econometric model. A multiple linear regression model was used to identify factors affecting the supply of fish to market by fishers.

According to the survey result, fishers obtained the share of $24 \%$ from Tilapia, $23.3 \%$ from Catfish and $25.7 \%$ from Carp in channel III. Generally, these market shares indicate that as the channel becomes long, the fishers share becomes lower and lower.

The study identified that there were different types of fish marketing channels in the study area. Fish was found to be supplied to Adama from Amude, Metoaleka and Kenteri landing sites. Likewise there was a channel which delivers fish directly to Addis Ababa from Amude and Metoaleka landing sites.

The structure of the market was analyzed by taking the share of the four sampled large firms from the average volume of fish trade per day for the period of 2012. The four firms Concentration Ratio (CR4) indicated that the four largest traders handled $58.51 \%$ of the total volume of purchased fish. Hence the structure of the fish market in the study area was oligopoly. Except high perishable nature of fish and high initial investment for whole sellers, there were no entry and exit barrier rules and regulations in fish trade. Fishers selling price was determined mainly by whole sellers. The total gross marketing margin was highest in the channel III that involves fishers, wholesalers, and consumers which was about 76, 76.7 and 74.3 for Tilapia, Catfish and Carp respectively.

The constraints in fish harvesting and marketing were identified by the fishers in the study areas. Among these illegal fishers who use very small mesh size net, high robbery risk on mesh and hook, low bargaining power of fishers, high cost of transportation to nearby towns and lack of value adding facilities were the major problems.

In order to identify the factors that determine the amount of fish supplied to the market, OLS regression analysis was employed with ten hypothesized variables. The result of OLS regression model analysis showed that the amount of fish which can be delivered by fishers to market was positively and significantly affected by education level, credit facility and ownership of fishing license.

\subsection{Conclusion and Recommendations}

The major factors identified as a problem in fish market chain analysis were related to both fish harvesting and marketing. Thus, appropriate interventions are required to alleviate these problems. The improvement of fishers bargaining power through fishery cooperatives is the best measure that should be targeted at reducing the oligopolistic nature of fish market. Lack of permanent fish marketplaces and shops in landing sites as well as nearby towns of Koka reservoir create problems on smoothening marketing activities. So, concerned authorities in respective areas should work for the improvement of these essential fish market infrastructures. Increasing the availability of credit facilities helps fishers as well as fishery cooperatives to have improved fishing equipments like gill net, motorized boats and refrigerators. These equipment help to boost the supply of fish to markets.

Education was found to be an important factor enhancing the supply of fish by fishers. Therefore, promoting adult education in fishery community needs to be considered as a priority area of intervention.

Provision of credit facility and encouraging fishers to be legal is very important for better harvesting of fish. Thus, there should be appropriate intervention that creates access to credit and attracts illegal fishers to be formally registered by easing the capital constraint they face. 
Delivering hydropower electric services in Amude landing site creates good opportunity for fishery cooperatives to use refrigerators and other value adding equipment. It is essential to use this opportunity for improvement of fish harvesting and marketing activities by augmenting it with necessary facilities required to preserve fish harvested and elongate its shelf life.

Acknowledgement: We would like to Acknowledge Ethiopian institute of Agricultural Research(EIAR) for funding this research work.

\section{REFERENCES}

Ahmed Naser-Alla, Graeme Macfadyen, Malcom Dickson and Diaa Al-Kenawy, 2012. Value

Chain Analysis of the Egyptian Aquaculture sector. IIFET 2012 Tanzania proceedings.P11.

Audun Lem, Uwe Tietze, Erhard Ruckes and Raymon van Anrooy, 2010.Fish marketing and credit in Viet Nam. FAO technical paper.p53.

Belay Kassa, 2010. Agricultural Research in the Ethiopian Institution of Higher Education: Current statues and Challenges: Proceedings of the first national stakeholders' conference dedicated to pastoral and emerging region, Addis Ababa, p131.

Bernard Marchal and M. Maes, 2003. Review of small water bodies and rivers in Eastern and southern African. Pp35-37.

Cramer,G.L.and W.Jensen ,1982. Agricultural Economics and Agribusiness, second edition. McGraw Hill Book Company, USA.p222.

Dawit Gebregziabher, 2010. Market chain analysis of poultry: the case of Alamata and AtsbiWonberta woredas of Tigray region.A M.Sc. Thesis presented to the school of graduate studies of Haramaya University, Ethiopia. P52.

Edilegnaw Wale, 2000. The Challenges in the Search for Efficient and Sustainable Rural C r e d it Institutions and Their Policy Implications in Ethiopia. PP 93-124. Proceedings of the fourth Annual Conference of Agricultural Economics Society of Ethiopia on Institutions for Rural Development. 23-24 November1999, Addis Ababa, Ethiopia.

FAO (Food and Agricultural Organization of United Nations), 2003a. Fishery Country Profile. (also available at http://www.fao.org/fi/fcp/en/ETH/ body.htm)

FAO (Food and Agricultural Organization of United Nations), 2008. Annual report, Rome Italy.
FAO (Food and Agricultural Organization of united nations), 2010a. The state of world fishery and Aquaculture 2010. Rome.p197 www.fao.org/ docrep/013/il1820e/il820e00.htm).

Food and Agricultural Organization of United $\mathrm{Na}-$ tions, 2010b. World Aquaculture Technical paper 500/1 Pp45-46, Rome Italy.

Gashaw Tesfaye, 2006. Population Dynamics and stock Assessment of Nile Tilapia (Koka, Z i w a y and Langano), Ethiopia, Msc thesis, Faculty of Biology and Chemistry, University of Bremen, Germany.

Guajarati Domodar, 2004. Basic of Econometrics, Fourth-ed. McGraw hill Company, in. United States Military Academy, West point.

Karugain N, 1990. Market chain analysis of pig in Central Peru, p23.

Letson Yoyola Phiri, Joseph Dzanja and Mafanizo Hara ,2012. Value Chain Analysis of L a k e Malawi Fish: A Case Study of Oreochromis spp. $17_{\mathrm{P}}$.

Mendoza and Mark Rosegant, 1995. Pricing conduct of spatially differentiated markets. Prices, products, and people. International Potato Center, Lima, Peru. Pp 343-356.

Pomeroy, R.S., 1989. The economics of production and marketing in small-scale fishery: $\quad \mathrm{M}$ a t a Iom, Leyte, Philippines. ICLARM. Poor Livestock Policy Initiative Working Paper 10, Rome: FAO Publishing Co.Pvt.Ltd., New Delhi. 370p.

Rab, M. A., Hap. N., Ahmed, M., Keang, S. and Viner, K., 2006. Socioeconomics and values of resources in Great Lake-Tonle Sap and Mekong-Bassac area: Results from a sample survey in Kampong Chhnang, Siem Reap and Kandal provinces. Phnom Penh, Cambodia.P 24 -28.

Raja Behara, 2005. Value Chain Analysis of Fishery in Puri and Ganjam District of Orissa. India. Pp40-42.

Soobasch Sweenarain, 2009. Implementation of a Regional Fisheries Strategy for the EasternSouthern Africa and India Ocean Region. P12.

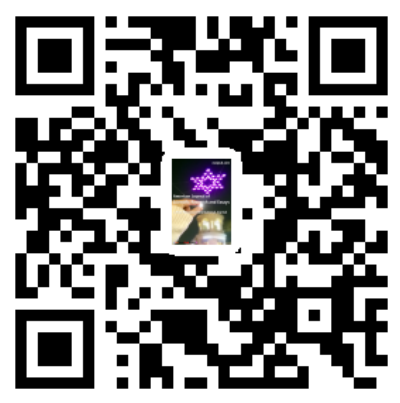

